\title{
TEROBOSAN HUKUM HAKIM TERKAIT PENCABUTAN SURAT PENOLAKAN PERKAWINAN DALAM MASA IDDAH
}

Kajian Putusan Nomor 287/Pdt.P/2017/PA.TA

\section{JUDICIAL BREAKTHROUGH ON THE REVOCATION OF MARRIAGE REJECTION LETTER DURING THE IDDAH PERIOD}

An Analysis of Decision Number 287/Pdt.P/2017/PA.TA

\author{
Muhamad Fauzi Arifin \& Lukman Santoso \\ Institut Agama Islam Negeri (IAIN) Ponorogo \\ J1. Pramuka No. 156 Ronowijayan Ponorogo 63471
}

Email: muh.fauziarifin22@yahoo.com dan lukmansantoso4@gmail.com

Naskah diterima: 2 Februari 2018; revisi: 20 November 2019; disetujui 19 Desember 2019

http://dx.doi.org/10.29123/jy.v12i3.331

\section{ABSTRAK}

Perkawinan dalam masa iddah secara hukum tidak dapat dilaksanakan sebelum masa iddah-nya habis. Berbeda halnya dengan Putusan Pengadilan Agama Tulungagung Nomor 287/Pdt.P/2017/PA.TA tentang pencabutan surat penolakan perkawinan dalam masa iddah. Penelitian terhadap putusan ini dilakukan dengan studi kepustakaan, dengan pendekatan yuridis dan analisis kualitatif. Kesimpulan dari penelitian ini bahwa, dasar hukum yang digunakan majelis hakim yaitu Pasal 153 ayat (2) Huruf b KHI, QS. At-Thalaq ayat 4, serta Pasal 53 KHI, yang diketahui dengan menggunakan metode penemuan hukum (rechtvinding), di antaranya: pertama, metode interpretasi sistematis dan metode istimba th digunakan untuk mengetahui bahwa masa iddah $\mathrm{W}$ (pemohon) bukan iddah hamil akan tetapi iddah qurû'; kedua, metode a contrario (argumen a contrario) terhadap Pasal 153 ayat (2) huruf c KHI, untuk mengetahui siapa pria yang menghamili $\mathrm{W}$ (pemohon), sekaligus sebagai dasar untuk mencabut surat penolakan perkawinan dari KUA tersebut; dan ketiga, silogisme terhadap Pasal 53 KHI, untuk mengetahui bahwa di antara $\mathrm{W}$ (pemohon) dengan $\mathrm{S}$ (calon suami) tidak ada halangan untuk
\end{abstract}

melangsungkan perkawinan.

Kata kunci: surat penolakan perkawinan; masa iddah; penemuan hukum.

\section{ABSTRACT}

No marriage is allowed for a woman during the period of iddah. This guidance is different from the substance of Tulungagung Religious Court Decision Number 287/ Pdt.P/2017/PA.TA that has revocated the marriage rejection letter during the iddah period. The research on this decision was carried out with a literature study with a juridical approach and qualitative analysis. The legal basis used by the panel of judges is Article 153 Paragraph 2 letter b KHI, QS. At-Thalaq verse 4 and Article 53 KHI. The judges also made some judicial lawmaking (rechtsvinding) that can be inferred as follows. First, the use of a systematic interpretation method and istimba th method for the conclusion that the iddah of the applicant $(W)$ in this case, is not iddah pregnant but iddah quru. Second, the use of the a-contrario argument against Article 153 Paragraph 2 letter c KHI to find out the man who has impregnated the applicant. 
This argument is also the logical basis for revoking the marriage rejection letter from the KUA. Third, the use of syllogism against Article $53 \mathrm{KHI}$ to make sure there is no obstacle of marriage between the applicant and her prospective husband (S).

Keywords: marriage rejection letter; the iddah period; judicial law-making.

\section{PENDAHULUAN}

\section{A. Latar Belakang}

Perkawinan dalam hukum Islam merupakan salah satu bentuk ibadah sekaligus untuk memenuhi kebutuhan dasar manusia dalam rangka memadu kasih sayang antara pria dan wanita. Selain itu, juga untuk memelihara kelangsungan hidup manusia, dengan melahirkan keturunan sebagai generasinya di masa yang akan datang (Mardani, 2011:3). Berdasarkan Pasal 1 Undang-Undang Nomor 1 Tahun 1974 tentang Perkawinan, dijelaskan bahwa perkawinan adalah ikatan lahir batin antara seorang pria dengan seorang wanita sebagai suami istri dengan tujuan membentuk keluarga yang bahagia dan kekal berdasarkan Ketuhanan Yang Maha Esa. Sedangkan dalam Kompilasi Hukum Islam (KHI), perkawinan adalah akad yang sangat kuat atau misaqan ghaliza untuk menaati perintah Allah SWT dan melaksanakannya merupakan ibadah.

Allah SWT telah menetapkan adanya aturan tentang perkawinan bagi manusia, dengan aturan-aturan yang tidak boleh dilanggar, sehingga hubungan pria dan wanita diatur secara terhormat (Al Hamdani, 2002:1-2). Merujuk pada KUHPerdata bahwa untuk dapat melangsungkan perkawinan harus dipenuhi syarat-syarat pokok demi sahnya suatu perkawinan, antara lain syarat materiel dan syarat formal (HS, 2008:63-64). Selain syarat tersebut, masih terdapat syarat khusus terhadap perkawinan yang dilaksanakan setelah adanya perceraian, karena setelah perceraian tersebut tentunya akan mengakibatkan berbagai dampak, salah satunya mengenai masa iddah bagi istri.

Iddah berasal dari bahasa Arab dari akar kata adda-ya'uddu- 'idatan dan jamaknya adalah 'idad yang secara arti kata berarti: "menghitung" atau "hitungan" (Munawwir, 2002:903). Sedangkan secara istilah iddah adalah waktu tunggu bagi wanita yang ditalak atau ditinggal mati suaminya, untuk mengetahui dengan yakin bebas atau tidaknya wanita itu dari hamil atau bagi wanita yang sudah putus haidnya, dimaksudkan sematamata ta'abbud (beribadah taat) kepada hukum Allah SWT (Sudarsono, 2001:277). Berdasarkan pengertian tersebut sudah jelas bahwa seorang istri yang telah diceraikan oleh suaminya, apabila akan melangsungkan perkawian kambali harus menunggu sampai waktu tunggu atau iddahnya habis, dan apabila perkawian tersebut tetap dilakukan selama masa iddah belum habis, maka Kantor Urusan Agama (KUA) harus menolak untuk melangsungkan perkawinan dengan mengeluarkan surat penolakan perkawinan.

Perkara yang diajukan di Pengadilan Agama Tulungagung, tentang permohonan pencabutan surat penolakan perkawinan, yaitu Putusan Nomor 287/Pdt.P/2017/PA.TA yang diputus pada tanggal 4 Oktober 2017. Perkara tersebut dilatarbelakangi karena adanya penolakan perkawinan antara $\mathrm{W}$ (pemohon) dengan $\mathrm{S}$ (calon suami) yang dilakukan oleh KUA Kecamatan Kedungwaru, Kabupaten Tulungagung, dengan dikeluarkannya Surat Penolakan Perkawinan Nomor B-252/ 
Kua.15.04.15/PW.01/09/2017, tanggal 12 September 2017. Pihak KUA menyatakan bahwa perkawinan tersebut tidak dapat dilaksanakan karena $\mathrm{W}$ (pemohon) diketahui hamil dalam masa iddah dan menganggap kehamilan tersebut terjadi karena hubungan badan antara $\mathrm{W}$ (pemohon) dengan mantan suaminya. Sesuai dengan Pasal 153 ayat (3) Huruf d KHI yang disebutkan bahwa masa iddah-nya sampai melahirkan.

Adapun duduk perkara dalam penetapan perkara tersebut diketahui bahwa $\mathrm{W}$ (pemohon) berstatus janda cerai, sebagaimana termuat dalam Akta Cerai Nomor 1352/AC/2017/PA.TA tertanggal 20 Juni 2017. Ketika perceraian tersebut $\mathrm{W}$ (pemohon) dalam keadaan suci ba'da dukhûl, dengan masa iddah terhitung sejak tanggal 20 Juni 2017 dan berakhir pada tanggal 20 September 2017. Ketika masa iddah tersebut belum berakhir, W (pemohon) hendak menikah dengan pria bernama $\mathrm{S}$ (calon suami) asal Kabupaten Trenggalek, antara keduanya sudah saling kenal sejak sebelum W (pemohon) bercerai dengan suaminya, dan telah melakukan hubungan badan hingga $\mathrm{W}$ (pemohon) diketahui hamil dua bulan.

Oleh karena W (pemohon) dalam kondisi hamil tersebut, maka W (pemohon) dan S (calon suami) ingin segera melangsungkan perkawinan. Layaknya persiapan perkawinan pada umumnya, persyaratan untuk melangsungkan perkawinan antara W (pemohon) dan S (calon suami) sebagaimana diatur dalam UU Nomor 1 Tahun 1974 dan Keputusan Menteri Agama Nomor 477 Tahun 2004 sudah dipenuhi. Namun Kepala KUA Kedungwaru Kabupaten Tulungagung menolak untuk melangsungkan perkawinan, dengan alasan adanya halangan persyaratan perkawinan sebagaimana termuat dalam Surat Kepala KUA Nomor B-252/Kua.15.04.15/PW.01/09/2017 tanggal 12 September 2017, serta penjelasan Kepala KUA bahwa W (pemohon) hamil dalam masa iddah. Perkawinan tersebut baru dapat dilaksanakan setelah habisnya masa iddah W (pemohon) atau sampai melahirkan.

W (pemohon) merasa keberatan atas surat penolakan yang dikeluarkan pihak KUA, karena antara keduanya tidak ada halangan untuk melangsungkan perkawinan baik menurut ketentuan agama maupun peraturan yang berlaku. Secara hukum, nikah hamil tidak dilarang berdasarkan ketentuan Pasal 53 KHI, oleh karena hal tersebut kemudian $\mathrm{W}$ (pemohon) mengajukan permohonan pencabutan surat penolakan di Pengadilan Agama Tulungagung. Di dalam persidangan, majelis hakim memberikan putusan mengabulkan semua petitum yang diajukan oleh W (pemohon).

Berangkat dari latar belakang di atas, di mana penetapan Pengadilan Agama Tulungagung bertolak belakang dengan Surat Penolakan Perkawinan yang dikeluarkan oleh KUA Kedungwaru, Kabupaten Tulungagung. Tentunya dalam hal ini majelis hakim berusaha keras mencari dasar hukumnya dari berbagai sumber, tidak hanya membaca teks hukum formal melainkan juga sumber non-hukum, karena hakim harus melakukan "fresh judgement" untuk menemukan hukum yang tepat, yakni dengan digunakannya beberapa metode penemuan hukum (rechtvinding). Hasil dari penemuan hukum tersebut dapat diketahui dari pertimbangan hukum. Berdasarkan pertimbangan hukum tersebut, dapat diketahui fakta-fakta yang terungkap dalam persidangan, yaitu kehamilan W (pemohon) ialah hasil hubungan badan di luar nikah yang dilakukan dengan $\mathrm{S}$ (calon suami), karena faktanya AM (mantan suami pemohon) telah pergi dan tidak diketahui keberadaannya 
sejak 1 (satu) tahun lalu. Sehingga hal tersebut digunakan sebagai dasar untuk mencabut surat penolakan perkawinan dari KUA Kedungwaru.

Hakikatnya seorang hakim memerlukan interpretasi hukum yang baru untuk menemukan hukum yang tepat, serta dapat melakukan terobosan yang tidak hanya terpaku pada undangundang saja untuk menciptakan suatu keadilan. Oleh karena itu, peneliti tertarik untuk meneliti permasalahan tersebut dengan melakukan analisis yuridis terhadap Putusan Nomor 287/Pdt.P/2017/ PA.TA tentang Pencabutan Surat Penolakan Perkawinan dalam Masa Iddah.

\section{B. Rumusan Masalah}

Berdasarkan latar belakang di atas, permasalahan yang akan dibahas dalam penelitian ini adalah bagaimana metode penemuan hukum (rechtvinding) oleh majelis hakim sehingga secara hukum penolakan perkawinan dalam masa iddah dari KUA dapat dicabut, dengan melakukan analisis yuridis terhadap Putusan Nomor 287/ Pdt.P/2017/PA.TA tentang pencabutan surat penolakan perkawinan dalam masa iddah?

\section{Tujuan dan Kegunaan}

Tulisan ini bertujuan untuk mengetahui metode penemuan hukum (rechtvinding) yang digunakan oleh majelis hakim dalam Putusan Nomor 287/Pdt.P/2017/PA.TA. Sedangkan kegunaan tulisan ini adalah untuk pengembangan ilmu hukum, khususnya mengenai teori penemuan hukum (rechtvinding) sebagai metode yang digunakan hakim, ketika menangani kasus yang secara hukum belum diatur dalam undangundang. Secara praktis manfaat penelitian ini dapat dijadikan sebagai literatur bagi akademisi maupun praktisi hukum, untuk memahami metode penemuan hukum (rechtvinding) dalam menangani suatu perkara dan hukum perkawinan dalam masa iddah.

\section{Tinjauan Pustaka}

\section{Hukum Perkawinan di Indonesia}

Kata perkawinan secara bahasa disebut dengan munakahat, sedangkan dalam bahasa Arab, yaitu Ahkam Al-Zawaj atau Ahkam Izwaj (Mardani, 2011:3), yang berarti akad (perjanjian) yang menjadikan halal hubungan seksual sebagai suami istri (Ramulyo, 2004:1). Secara istilah perkawinan adalah ikatan lahir batin seorang pria dan wanita untuk hidup bersama dalam rumah tangga, yang dilaksanakan menurut ketentuan hukum syariat Islam (Hamid, 2000:1). Sedangkan dalam Pasal 1 UU Nomor 1 Tahun 1974, perkawinan adalah ikatan lahir batin antara seorang pria dengan seorang wanita sebagai suami istri dengan tujuan membentuk keluarga yang bahagia dan kekal berdasarkan Ketuhanan Yang Maha Esa.

Rukun dan syarat perkawinan di Indonesia termuat dalam UU Perkawinan Nomor 1 Tahun 1974 dan Kompilasi Hukum Islam, di dalam peraturan tersebut terdapat rukun dan syarat yang harus dipenuhi oleh para subjek hukum yang merupakan unsur atau bagian dari akad perkawinan. Secara tegas rukun perkawinan disebutkan dalam Pasal 14 Kompilasi Hukum Islam, sedangkan syarat perkawinan diatur dalam Pasal 6-12 UU Nomor 1 Tahun 1974 tentang Perkawinan, di antaranya:

a. Calon suami, syaratnya yaitu: bukan mahram dari calon istri, atas kemauan sendiri, jelas orangnya dan tidak sedang ihram haji. 
b. Calon istri, syaratnya yaitu: tidak bersuami, bukan mahram, tidak sedang dalam masa iddah, atas kemauan sendiri, jelas orangnya dan tidak sedang berihram haji (Al Hamdani, 2002:67-69).

c. Wali nikah, syaratnya yaitu: laki-laki, dewasa, sehat akalnya, tidak dipaksa, adil, dan tidak sedang ihram haji (Syarifuddin, 2006:69).

d. Dua orang saksi, syaratnya yaitu: laki-laki, baligh, waras akalnya, adil, dapat mendengarkan dan melihat, tidak dipaksa, tidak sedang ihram haji, dan memahami bahasa yang dipergunakan untuk ijab dan qabul (Al Hamdani, 2002:68).

e. Ijab dan qabul, syaratnya yaitu harus digunakan kata-kata yang dapat dipahami oleh masing-masing pihak yang melangsungkan akad nikah (Rofiq, 2003:97).

f. Mahar adalah sejumlah uang atau barang yang mempunyai nilai ekonomis, yang ditentukan berdasarkan kesepakatan kedua belah pihak.

\section{Masa Iddah Wanita Hamil Karena Zina}

Iddah secara bahasa berasal dari kata kerja 'adda-ya'uddu-'addan dan kata al- 'iddatu jamaknya adalah 'idad yang secara arti kata berarti menghitung, hitungan atau jumlah (Munawwir, 2002:903). Sedangkan secara istilah iddah adalah masa tunggu yang dilakukan seorang istri yang putus pernikahannya dengan suaminya, baik putus karena perceraian, kematian, maupun atas putusan pengadilan (Daradjat, 2013:274). Masa iddah tersebut hanya berlaku bagi istri yang sudah melakukan hubungan suami istri ( $b a$ 'da dukhûl). Lain halnya apabila istri belum melakukan hubungan suami istri (qabla dukhûl) maka tidak berlaku baginya masa iddah (Ali, 2012:87), dan setelah terjadi perceraian tersebut selama menjalani masa iddah seorang wanita dilarang untuk menikah dengan orang lain (Hasunah \& Susanto, 2016:101).

Ketentunan mengenai masa iddah dalam hukum positif termuat dalam Pasal 11 UU Nomor 1 Tahun 1974 tentang Perkawinan. Selanjutnya mengenai batas waktu tunggu diatur dalam Pasal 39 Peraturan Pemerintah Nomor 9 Tahun 1975 tentang Pelaksanaan UU Nomor 1 Tahun 1974 tentang Perkawinan. Sedangkan ketentuan masa iddah menurut Kompilasi Hukum Islam termuat dalam Pasal 153. Selain peraturan tersebut, secara eksplisit dalam hukum Islam juga menjelaskan mengenai masa iddah, kewajiban menjalani masa iddah disebutkan dalam QS. Al Baqarah ayat 228 serta dalam QS. At Thalaq ayat 4 (Jauharatun, 2016:160).

Sebagaimana termuat dalam Kompilasi Hukum Islam Pasal 153, masa iddah terbagi menjadi beberapa macam, salah satunya karena putusnya pernikahan yang disebabkan karena perceraian. Iddah karena percaraian tersebut terdapat dua klasifikasi, di antaranya:

a. Dalam keadaan hamil, apabila seorang istri diceraikan oleh suaminya dalam keadaan hamil, maka iddah-nya sampai melahirkan kandungannya.

b. Dalam keadaan tidak hamil, apabila seorang istri diceraikan oleh suaminya sebelum terjadi hubungan 
kelamin (qabla dukhûl), maka tidak berlaku baginya masa iddah. Namun apabila telah terjadi hubungan kelamin (ba'da dukhûl), maka masa iddah yang berlaku adalah tiga kali suci dengan sekurang-kurangnya 90 hari (iddah qurû').

Mengenai kondisi seorang wanita yang kadang mengalami haid, tidak mengalami haid, hamil, menyusui, ataupun karena kematian suaminya ketika dalam masa iddah, maka terjadi pergantian iddah yang harus dijalani seorang wanita, di antaranya:

a. Pergantian iddah berdasarkan haid menjadi iddah berdasarkan hitungan bulan;

b. Pergantian iddah berdasarkan hitungan bulan menjadi iddah berdasarkan haid;

c. Iddah berdasarkan haid atau bulan berubah menjadi iddah melahirkan.

Ketentuan iddah wanita hamil karena zina dijelaskan dalam Kompilasi Hukum Islam Pasal 53, sebagai berikut:

a. Seorang wanita hamil di luar nikah, dapat dikawinkan dengan pria yang menghamilinya.

b. Perkawinan dengan wanita hamil yang disebut pada ayat (1) dapat dilangsungkan tanpa menunggu lebih dahulu kelahiran anaknya.

c. Dengan dilangsungkannya perkawinan pada saat wanita hamil, tidak diperlukan perkawinan ulang setelah anak yang dikandung lahir.
Ketentuan iddah wanita hamil karena zina, jika menikah dengan laki-laki yang tidak menghamilinya tidak dijelaskan secara implisit di dalam Kompilasi Hukum Islam. Sementara dalam Pasal 53 ayat (1) hanya disebutkan wanita hamil di luar nikah, dapat dikawinkan dengan pria yang menghamilinya. Sedangkan dalam Pasal 53 ayat (2), dapat diperoleh penjelasan secara eksplisit bahwa jika wanita hamil karena zina menikah dengan laki-laki yang menghamilinya, maka tidak ada kewajiban untuk menjalankan iddah hamil. Seperti dijelaskan dalam ayat (2) bahwa wanita tersebut dapat langsung dikawinkan dengan lakilaki yang menghamilinya tanpa harus menunggu lebih dahulu kelahiran anaknya.

Ketentuan Pasal 53 ayat (2) perlu pemikiran khusus, serta pengkajian ulang tentang iddah untuk wanita hamil karena zina, karena di dalam Al Quran dan Sunnah Rasulullah SAW tidak ada ketetapan yang mengatur tentang iddah wanita hamil karena zina. Memang ketentuan yang terdapat dalam Pasal 53 ayat(1) dan (2) merupakan suatu bagian integral (tidak terpisahkan) dari Pasal 53, yakni antara ayat yang satu dengan ayat yang lain merupakan satu kesatuan, sehingga tidak mungkin terjadi kontradiksi antar ayat dalam Pasal 53 (Ghazaly, 2008:124).

\section{Metode Penemuan Hukum (Rechtvinding)}

Penemuan hukum adalah proses pembentukan hukum oleh hakim atau aparat hukum lainnya yang ditugaskan untuk penerapan peraturan hukum umum pada peristiwa hukum konkret, karena tidak ada peraturan perundangundangan yang lengkap selengkap-lengkapnya dan jelas sejelas-jelasnya. Oleh karena hukumnya tidak lengkap dan tidak jelas, maka harus dicari 
dan diketemukan (Mertokusumo, 2010:48). Dalam praktik di pengadilan, hakim selalu dihadapkan pada peristiwa konkret, secara yuridis hakim tidak boleh untuk menolak suatu kasus atau perkara dengan alasan tidak ada hukum. Oleh karena itu hakim harus berperan untuk mengisi kekosongan hukum, berusaha untuk menafsirkan suatu ketentuan hukum kurang jelas. Jadi dalam penemuan hukum yang penting adalah bagaimana mencarikan atau menemukan hukumnya untuk peristiwa konkret. Ada tiga dasar pemikiran untuk melakukan penemuan hukum oleh hakim, yaitu:

a. Karena peraturannya tidak ada, tetapi esensi perkaranya mirip dengan suatu peraturan lain sehingga dapat diterapkan dalam perkara tersebut.

b. Peraturannya memang ada, tetapi kurang jelas sehingga hakim perlu menafsirkannya.

c. Peraturan juga sudah ada, tetapi sudah tidak sesuai lagi dengan kondisi dan kebutuhan masyarakat.

Dasar hukum bagi hakim dalam melakukan penemuan hukum yakni termuat dalam Pasal 1 ayat (1) UU Nomor 48 Tahun 2009 tentang Kekuasaan Kehakiman, menyebutkan: "Kekuasaan kehakiman adalah kekuasaan negara yang merdeka untuk menyelenggarakan peradilan guna menegakkan hukum dan keadilan berdasarkan Pancasila demi terselenggaranya Negara Hukum Republik Indonesia." Kata "merdeka" di sini berarti bebas, jadi kekuasaan kehakiman adalah bebas untuk menyelenggarakan peradilan, dengan maksud bebas untuk mengadili dan bebas dari campur tangan dari pihak ekstra yudisial. Kebebasan hakim ini memberi wewenang kepada hakim untuk melakukan penemuan hukum agar lebih leluasa. Scholten menegaskan,"het recht is er, doch het moet gevonden worden; in de vondst zit het nieuwe" (hukum itu telah ada, tetapi masih harus ditemukan; dalam hukum yang ditemukan terdapat hal yang baru). Dengan kata lain, hukum itu ada dalam undang-undang, tetapi masih harus ditemukan (Putro, 2011:184).

Dworkin menyatakan bahwa para hakim memang selalu dibatasi oleh hukum, sehingga tidak ada hakim melampaui hukum. Permasalahannya, dalam "hard cases" tidak ada standar penerapan yang wajib diikuti oleh hakim, karena hukum adalah jaringan tanpa ikatan, yang mana penyelesaian perkara hukum selalu ada jawaban yang benar. Menghadapi kasus yang rumit (hard cases) tersebut, Dworkin menyarankan hakim tidak cukup menyalin pasal dalam peraturan perundang-undangan semata, melainkan harus melakukan interpretasi (Putro, 2011:174-178). Telah dikemukakan bahwa tidak seluruhnya peraturan perundang-undangan yang ada itu jelas dan lengkap, yang dalam hal ini memerlukan peran hakim untuk mencari, menggali, dan menemukan hukumnya. Dalam hal ini hakim tidak hanya bertindak sebagai "mulut" undang-undang, melainkan juga "mulut" keadilan yang menyuarakan perasaan keadilan yang hidup di tengah-tengah masyarakat (Elias, 2014:2). Sehingga untuk menemukan hukumnya terdapat beberapa metode penemuan hukum, di antaranya:

\section{a. Metode Interpretasi (Penafsiran)}

Metode interpretasi adalah metode untuk menafsirkan terhadap teks perundang-undangan yang tidak jelas, agar perundang-undangan tersebut dapat diterapkan terhadap peristiwa konkret tertentu. Dengan kata lain 
apabila undang-undangnya tidak jelas, hakim wajib menafsirkannya sehingga hakim dapat membuat suatu keputusan yang adil dan sesuai dengan maksud hukum yaitu kepastian hukum.

b. Metode Argumentasi (Penalaran)

Metode argumentasi disebut juga dengan metode penalaran hukum, redenering atau reasoning. Penalaran hukum merupakan sebuah proses upaya untuk mencapai putusan pengadilan. Namun, proses penalaran hukum dalam bentuk distrukturkan seolah-olah didasarkan logika mekanis, padahal dalam kenyataannya penalaran hukum tidak mungkin tanpa merujuk kebijakan yang mendasari hukum.

c. Metode Eksposisi (Konstruksi Hukum)

Metode eksposisi adalah metode untuk menjelaskan kata-kata atau membentuk pengertian (hukum), bukan untuk menjelaskan barang. Pengertian hukum yang dimaksud adalah konstruksi hukum yang merupakan alat-alat yang dipakai untuk menyusun bahan hukum yang dilakukan secara sistematis dalam bentuk bahasa dan istilah yang baik. Menyusun di sini ialah menyatukan apa yang termasuk dalam satu bidang yang sama, satu pengertian yang sama (Mertokusumo, 2010:145).

d. Metode Penemuan Hukum Islam
Hukum dalam pengertian ulama ushul adalah khitab (intruksi-wacana) Allah SWT menyangkut perbuatan orang mukalaf yang berisi tuntutan, izin atau penetapan. Kemudian kumpulan dari hukum-hukum (hukum syari'at) itu kemudian dinamakan dengan fiqh. Sedangkan dalil yang dapat diambil sebagai hukum syariat secara hierarki adalah: Al Quran, As-Sunnah, Al-Ijma' dan Qiyas (Musahadi, 2009:22).

Di era sekarang, peradilan agama adalah salah satu lembaga resmi yang mempunyai tugas untuk menampakkan hukum agama. Kendati demikian setiap perkara yang masuk di pengadilan agama, sudah seharusnya yang menjadi dominan di sana adalah juga menggunakan metode penemuan hukum Islam dalam setiap putusannya. Terdapat beberapa metode penemuan hukum Islam yang dapat dijadikan rujukan oleh hakim di lingkungan peradilan agama, di antaranya:
a. Metode Istimbath
b. Metode Ijtihad
c. Metode Ijma'
d. Metode Qiyas
e. Metode Istishlah
f. Metode Ihtishan
g. Metode Ihtishab
h. Metode $A l$ ' $U r f u$
i. Metode Sadduzzari'ah 
4. Deskripsi Putusan Nomor 287/

Pdt.P/2017/PA.TA tentang Pencabutan

Surat Penolakan Perkawinan dalam

Masa Iddah

Perkara ini diajukan oleh seorang wanita bernama W sebagai pemohon ke Pengadilan Agama Tulungagung pada tanggal 12 September 2017. Setelah majelis hakim membaca dan memeriksa berkas perkara yang diajukan oleh $\mathrm{W}$ (pemohon), di mana dalam berkas permohonan tersebut telah disebutkan secara deskriptif mengenai peristiwa hukum, fakta hukum dalam beberapa posita secara runtut.

Awalnya W (pemohon) bermaksud untuk menikah dengan seorang pria bernama $\mathrm{S}$ (calon suami). Ketika akan melangsungkan perkawinan, W (pemohon) telah berstatus sebagai janda cerai atas cerai gugat yang diajukannya terhadap AM (mantan suami pemohon). W (pemohon) menyatakan bahwa yang melatarbelakangi diajukannya cerai gugat tersebut karena AM (mantan suami pemohon) pergi meninggalkannya sejak 1 (satu) tahun yang lalu, dan selama itu pemohon tidak diberikan nafkah baik lahir maupun batin. Sebagaimana termuat dalam Akta Cerai yang dikeluarkan oleh Pengadilan Agama Tulungagung Nomor 1352/AC/2017/PA.TA, tertanggal 20 Juni 2017. Pada saat perceraian tersebut, W (pemohon) dalam keadaan suci $b a$ 'da dukhul, dengan masa iddah terhitung sejak terjadinya perceraian tepatnya pada tanggal 20 Juni 2017, dan masa iddah W (pemohon) berakhir sampai tanggal 20 September 2017.

Sebelum tarjadi perceraian antara W (pemohon) dengan AM (mantan suami pemohon), W (pemohon) sudah kenal dengan $\mathrm{S}$ (calon suami), tepatnya sejak 8 bulan yang lalu, dan selama 8 bulan tersebut antara W (pemohon) dengan S (calon suami) sudah beberapa kali melakukan hubungan badan layaknya suami istri. Setelah W (pemohon) resmi bercerai dengan suaminya diketahui bahwa $\mathrm{W}$ (pemohon) tersebut hamil 2 bulan, sebagai akibat hubungan terlarang yang dilakukan oleh $\mathrm{W}$ (pemohon) dengan $\mathrm{S}$ (calon suami). Setelah mengetahui bahwa W (pemohon) telah hamil 2 bulan, maka $\mathrm{W}$ (pemohon) ingin segera menikah dengan $\mathrm{S}$ (calon suami) di hadapan Pegawai Pencatat Nikah pada KUA Kecamatan Kedungwaru, Kabupaten Tulungagung, sesuai domisili keberadaan W (pemohon) bertempat tinggal.

Persyaratan-persyaratan

untuk melangsungkan pernikahan antara $\mathrm{W}$ (pemohon) dengan S (calon suami) sebagaimana diatur dalam UU Nomor 1 Tahun 1974 dan Keputusan Menteri Agama Nomor 477 Tahun 2004 telah dipenuhi. Akan tetapi ketika hendak mendaftarkan perkawinan tersebut, ternyatapihak KUAmenolak untuk melangsungkan pernikahan $\mathrm{W}$ (pemohon) dengan S (calon suami), dengan alasan adanya halangan pernikahan sebagaimana termuat dalam Surat Kepala KUA, tertanggal 12 September 2017, Nomor B-252/Kua.15.04.15/PW.01/09/2017 tentang penolakan perkawinan, serta penjelasan Kepala KUA bahwa W (pemohon) hamil dalam masa iddah, dan menyatakan bahwa iddah W (pemohon) berakhir sampai dilahirkannya bayi yang ada dalam kandungannya. Sehingga perkawinan tersebut baru dapat dilaksanakan setelah habisnya masa iddah hamil W (pemohon) yakni sampai melahirkan.

Mengetahui hal itu, W (pemohon) merasa keberatan atas surat penolakan KUA yang menolak untuk melangsungkan perkawinan $\mathrm{W}$ (pemohon) dengan $\mathrm{S}$ (calon suami), karena antara keduanya tidak ada halangan untuk melangsungkan perkawinan, baik menurut 
katentuan agama maupun peraturan yang berlaku. Mengenai keterangan dari Kepala KUA yang menyatakan adanya larangan menikah dalam masa iddah bagi $\mathrm{W}$ (pemohon).

Hal ini tentunya tidak benar dan tidak sesuai dengan fakta, sebab kehamilan W (pemohon) adalah hasil hubungan badan di luar nikah antara $\mathrm{W}$ (pemohon) dengan $\mathrm{S}$ (calon suami), bukan dengan suaminya dahulu. S (calon suami) juga merasa bertanggung jawab atas kehamilan W (pemohon), serta ingin segera menikah dengan W (pemohon), karena nikah hamil tidak dilarang menurut ketentuan Pasal 53 Kompilasi Hukum Islam. Selain hal itu, W (pemohon) ingin segera menikah dengan $\mathrm{S}$ (calon suami) agar anak yang ada dalam kandungannya dapat lahir dalam perkawinan yang sah (Putusan Nomor 287/ Pdt.P/2017/PA.TA).

\section{METODE}

Jenis penelitian yang digunakan oleh peneliti ialah penelitian hukum normatif, yaitu penelitian hukum yang dilakukan dengan cara meneliti bahan pustaka atau data sekunder (Soekanto \& Mamudji, 2010:13-14). Di mana data sekunder yang digunakan terdiri dari bahan hukum primer, sekunder, dan tersier, sehingga penelitian ini termasuk penelitian kepustakaan (library research) (Soekanto, 2006:52). Pentingnya peneliti menggunakan jenis penelitian hukum normatif adalah data yang diteliti berupa bahan hukum primer atau dokumen resmi dari Pengadilan Agama Tulungagung, yaitu penetapan Putusan Nomor 287/Pdt.P/2017/PA.TA, sehingga teknik pengumpulan data yang digunakan adalah studi dokumentasi.

Pendekatanyangdigunakandalampenelitian ini adalah pendekatan yuridis normatif, yaitu prosedur penelitian yang mengacu pada bahan hukum primer berupa norma-norma hukum yang terdapat dalam peraturan perundang-undangan dan putusan pengadilan serta norma hukum yang ada dalam masyarakat (Ali, 2011:105), dengan melihat sinkronisasi suatu aturan dengan aturan lainnya secara hierarki. Teknik analisis data dalam penelitian ini adalah deskriptif analitik, yaitu peneliti mendeskripsikan terlebih dahulu secara sistematis, faktual dan akurat, terhadap perkara yang diteliti (Koentjaraningrat, 2008:19), yaitu Putusan Nomor 287/Pdt.P/2017/PA.TA. Kemudian setelah perkara tersebutdideskripsikan, selanjutnya akan dianalisis dengan teori metode penemuan hukum (rechtvinding), serta menguraikan peraturan perundang-undangan yang menjadi objek penelitian, kemudian ditarik pada suatu kesimpulan (Ali, 2011:105-106).

\section{HASIL DAN PEMBAHASAN}

\section{A. Analisis Yuridis terhadap Putusan Nomor 287/Pdt.P/2017/PA.TA \\ tentang Pencabutan Surat Penolakan Perkawinan dalam Masa Iddah}

Peneliti mencoba melihat dan menganalisis terhadap Putusan Nomor 287/Pdt.P/2017/PA.TA, yaitu penetapan tentang pencabutan atas surat penolakan perkawinan dalam masa iddah, yang dikeluarkan oleh KUA Kedungwaru Kabupaten Tulungagung. Berdasarkanidentitas W(pemohon) yang beralamatkan di Dusun Gendingsari, Desa Gendingan, Kecamatan Kedungwaru, Kabupaten Tulungagung, maka sudah tepat jika Pengadilan Agama Tulungagung yang berwenang untuk mengadili perkara tersebut di tingkat pertama. Sesuai dengan UU Nomor 3 Tahun 2006 tentang Peradilan Agama, perkara ini menjadi wewenang Pengadilan Agama Tulungagung, karena menjadi salah satu daerah yurisdiksinya (Ali, 2012:1). 
Setelah Majelis hakim melihat peristiwa dan fakta hukum yang tersaji dan terungkap di dalam persidangan, selanjutnya dalam merumuskan pertimbangan hukum majelis hakim harus menemukan hukumnya yang sesuai dengan pemecahan perkara tersebut. Karena secara yuridis hakim tidak boleh menolak suatu perkara dengan alasan tidak ada hukumnya dan hakim harus melakukan penemuan hukum dengan berperan untuk mengisi kekosongan hukum, berusaha untuk menafsirkan suatu ketentuan hukum yang kurang jelas. Dalam penemuan hukum, sekalipun terdapat kebebasan hakim dalam memutus suatu perkara, akan tetapi hakim harus tetap di bawah undangundang, dengan demikian putusan hakim tidak akan berisi lebih dari apa yang terdapat dalam undang-undang yang berhubungan dengan perkara tersebut (Mertokusumo, 2010:52-53).

Berdasarkan analisis majelis hakim terhadap fakta dan peristiwa hukum yang terungkap dalam persidangan, sesuai ketentuan Pasal 50 ayat (1) UU Nomor 48 Tahun 2009 tentang Kekuasaan Kehakiman, dijelaskan: "Putusan pengadilan selain harus memuat alasan dan dasar putusan, juga memuat pasal tertentu dari peraturan perundang-undangan yang bersangkutan atau sumber hukum tak tertulis yang dijadikan dasar untuk mengadili." Dapat dipahami bahwa, hakim dapat turut serta menemukan mana yang merupakan hukum dan mana yang tidak merupakan hukum, seperti yang dikatakan Scholten bahwa hakim menjalankan undang-undang itu selalu rechtvinding (turut serta menemukan hukum) (Mahfiana, 2005:106). Dalam hal ini, yang dilakukan oleh peneliti adalah menganalisis Putusan Nomor 287/ Pdt.P/2017/PA.TA dengan teori penemuan hukum (rechtvinding).
Penemuan hukum adalah proses pembentukan hukum oleh hakim atau aparat hukum lainnya yang ditugaskan untuk penerapan peraturan hukum umum pada peristiwa hukum konkret. Atau dengan kata lain penemuan hukum merupakan proses konkretisasi atau individualisasi peraturan hukum (das sollen) yang bersifat umum dengan mengingat akan peristiwa konkret (das sein) tertentu (Mertokusumo, 2010:48). Sedangkan kekurangan undangundang menurut aliran penemuan hukum, hendaknya diisi oleh hakim dengan penggunaan hukum-hukum logika (silogisme) sebagai dasar utamanya (Ali, 2011:102). Di sini bukan hasil penemuan hukum yang merupakan titik sentral, walaupun tujuannya adalah menghasilkan putusan, melainkan metode yang digunakan. Sehingga peneliti menyimpulkan, bahwa dalam penemuan hukum yang penting adalah bagaimana mencarikan dan menemukan hukumnya untuk peristiwa konkret.

Berikut ini adalah beberapa analisis yang dilakukan dengan menggunakan teori penemuan hukum (rechtvinding), yang digunakan oleh majelis hakim dalam Putusan Nomor 287/ Pdt.P/2017/PA.TA tentang pencabutan atas surat penolakan perkawinan dalam masa iddah, di antaranya:

\section{Metode Interpretasi Sistematis (logis) dan Metode Istimbath}

Metode Interpretasi Sistematis (logis) yaitu menafsirkan peraturan perundang-undangan dengan menghubungkannya dengan peraturan hukum lain, sehingga berbagai ketentuan yang ada di dalamnya terdapat kesaling-terhubungan yang dapat menentukan suatu makna (Putro, 2011:184; Tobroni, 2016:294). Berdasarkan 
analisis dalam penelitian ini terhadap Putusan Nomor 287/Pdt.P/2017/PA.TA, majelis hakim dalam penemuan hukumnya telah sesuai dengan metode interpretasi sistematis, tekait penetapan masa iddah yang harus dijalani oleh W (pemohon).

Hal ini dapat dilihat dalam pertimbangan hukumnya, bahwa majelis hakim mengaitkan beberapa peraturan perundang-undangan secara sistematis dengan menggunakan sumber hukum positif dan juga sumber hukum Islam, di antaranya berdasarkan firman Allah SWT dalam QS. At-Thalaq ayat 4, dan Pasal 39 ayat (1) huruf b Peraturan Pemerintah Nomor 9 Tahun 1975 tentang Pelaksanaan Undang-Undang Nomor 1 Tahun 1974 tentang Perkawinan jo. Pasal 153 ayat (2) huruf b Kompilasi Hukum Islam, yang berbunyi:

"Apabila perkawinan putus karena perceraian, waktu tunggu bagi yang masih haid ditetapkan 3 (tiga) kali suci dengan sekurang-kurangnya 90 (sembilan puluh) hari, dan bagi yang tidak haid ditetapkan 90 (sembilan puluh) hari."

Setelah ditemukan dasar hukum dalam hukum positif, selanjutnya digunakan pula metode istimbath untuk memberikan kepastian hukum secara hukum agama, yakni dengan cara menetapkan (mengeluarkan) hukum Islam dari dalil nash, baik dari ayat-ayat Al Quran maupun dariAs-Sunnah, yang lafadz (perkataannya) sudah jelas/pasti (qath'i). Sebagaimana pertimbangan hukum dalam perkara ini, digunakan pula firman Allah SWT dalam QS. Al-Baqarah ayat 228 sebagai rujukan penetapan masa iddah yang wajib dijalani oleh $\mathrm{W}$ (pemohon), yang inti ayat tersebut adalah bagi istri yang ditalak hendaknya menahan diri 3 (tiga) kali suci/qurû'. Ayat ini digunakan oleh hakim karena ketentuan yang terkandung dalam ayat tersebut bisa berlaku baik untuk cerai gugat maupun cerai talak.
Berdasarkan interpretasi sistematis terhadap pasal dan ayat tersebut di atas, maka masa iddah yang harus dijalani oleh W (pemohon) bukan iddah hamil, akan tetapi iddah qurû'. Sebagaimana dalam pertimbangan hukumnya berbunyi sebagai berikut:

"Menimbang, bahwa oleh karenanya, maka iddah yang harus dijalani pemohon adalah iddah qurû', bukan iddah hamil,"

"Menimbang, bahwa oleh karena sesudah putusan dijatuhkan (setelah terjadi perceraian pemohon dengan AM), pemohon hanya mengalami dua kali masa suci (dua qurû'), berdasarkan Pasal 153 ayat (2) Huruf b dan firman Allah SWT dalam QS. At-Thalaq ayat 4, maka masa iddah-nya ditetapkan tiga bulan (90 hari)."

Menurut penelitian, majelis hakim menggunakan metode interpretasi sistematis (logis) tersebut, dapat diketahui berdasarkan digunakannya peraturan perundang-undangan yang terdiri dari beberapa pasal yang saling melengkapi, juga digunakan pula ayat-ayat $\mathrm{Al}$ Quran sebagai rujukan bagi hakim pengadilan agama dalam melakukan penemuan hukum, untuk menentukan suatu makna dari peraturan tersebut (Putro, 2011:206).

Menurut penelitian, bahwa ditetapkannya iddah qurû' kepada W (pemohon) karena selama dalam masa kehamilan, W (pemohon) yang tidak mengalami haid ketika menjalankan masa iddah-nya, yaitu dari masa iddah yang dihitung dari 3 (tiga) kali suci menjadi iddah qurû' atau 90 (sembilan puluh) hari (Hasunah \& Susanto, 2016:103), terhitung sejak tanggal perceraian W (pemohon) dengan suaminya, tepatnya sejak dikeluarkannya Akta Cerai Nomor 1352/ AC/2017/PA.TA pada tanggal 20 Juni 2017 dan berakhir sampai tanggal 20 September 2017. Setelah habis masa iddah qurû' tersebut, 
kemudian W (pemohon) boleh melangsungkan perkawinannya dengan $\mathrm{S}$ (calon suami) (Jauharatun, 2016:164). Dalam hal kata qurû' di atas sebagai masa yang harus ditunggu oleh seorang wanita yang diceraikan oleh suaminya ketika tidak mengalami haid.

\section{Metode $A$ Contrario (Argumen a Contrario)}

Metode $A$ Contrario (Argumen a Contrario), yaitu menjelaskan makna undangundang dengan didasarkan pada pengertian yang sebaliknya dari peristiwa konkret yang dihadapi dengan peristiwa yang diatur dalam undangundang (Sutiyoso, 2012:139-140). Berdasarkan analisis penelitian terhadap putusan tersebut, metode ini digunakan untuk mengetahui siapa pria yang telah menghamili W (pemohon), sehingga dapat diperoleh suatu kejelasan mengenai status kehamilan W (pemohon), sebagai dasar yang digunakan untuk membatalkan surat penolakan perkawinan yang dikeluarkan oleh KUA Kedungwaru Kabupaten Tulungagung.

Berdasarkan pemeriksaan sidang, bahwa dalam ketentuan hukum sebagaimana disebutkan dalam Pasal 153 ayat (2) huruf c Kompilasi Hukum Islam, dijelaskan: “Apabila perkawinan putus karena perceraian sedang janda tersebut dalam keadaan hamil, waktu tunggu ditetapkan sampai melahirkan." Sehingga ketentuan hukum ini berlaku sebaliknya, bahwa masa iddah yang harus dijalani oleh $\mathrm{W}$ (pemohon) bukan iddah hamil atau sampai melahirkan, akan tetapi masa iddah yang berlaku bagi $\mathrm{W}$ (pemohon) adalah iddah qurû' yaitu 90 (sembilan puluh) hari. Sebab dalam pemeriksaan sidang terbukti bahwa kehamilan W (pemohon) bukan dengan suaminya, melainkan sebagai akibat dari hubungan badan di luar nikah yang dilakukannya dengan $\mathrm{S}$ (calon suami).

Hal ini sesuai dengan aturan hukum mengenai iddah hamil, bahwa ketetapan iddah hamil tidak dapat diberlakukan terhadap W (pemohon), karena kehamilannya tersebut bukan dengan suaminya, akan tetapi dengan orang lain meskipun kehamilan W (pemohon) tersebut terjadi dalam masa iddah. Oleh karena itu, peneliti setuju dengan pertimbangan majelis hakim bahwa surat penolakan perkawinan dalam masa iddah yang dikeluarkan oleh pihak KUA tidak terbukti dan dinyatakan tidak mempunyai kekuatan hukum, sebagaimana dalam putusannya berbunyi sebagai berikut:

"Menimbang, bahwa berdasar pengakuan pemohon dan $\mathrm{S}$ (calon suami) di depan persidangan, bahwa kehamilan pemohon dan janin yang dikandung pemohon adalah hasil hubungan seksual di luar nikah antara pemohon dengan $\mathrm{S}$ (calon suami) atas dasar suka sama suka. Dengan demikian, maka janin yang dikandung oleh pemohon bukan hasil hubungan badan dengan mantan suaminya (AM) tetapi hasil hubungan badan dengan $\mathrm{S}$ (calon suami) di luar nikah."

\section{Silogisme}

Mengenai perkawinan antara $\mathrm{W}$ (pemohon) dengan $\mathrm{S}$ (calon suami) di mana $\mathrm{W}$ (pemohon) dalam kondisi hamil, majelis hakim menggunakan silogisme, yaitu dengan menghubungkan faktafakta tersebut (premis minor) dengan unsur-unsur Pasal 53 ayat (1) KHI (premis mayor) dari surat permohonan yang diajukan oleh W (pemohon), untuk menganalisis fakta-fakta tersebut terbukti dan dapat dibenarkan (Elias, 2014:7). Sehingga silogisme mengenai perkawinan tersebut adalah sebagai berikut: 
Tabel 1. Silogisme Putusan Nomor 287/Pdt.P/2017/PA.TA

\begin{tabular}{lll}
\hline Premis Mayor & $: \begin{array}{l}\text { Seorang wanita hamil di luar nikah, dapat dikawinkan dengan pria yang } \\
\text { menghamilinya. }\end{array}$ \\
\hline Premis Minor & $:$ & W (pemohon) adalah seorang wanita yang hamil di luar nikah. \\
\hline $\begin{array}{l}\text { K o n k 1 u s i } \\
\text { kesimpulan) }\end{array}$ & $:$ & W (pemohon) dapat dikawinkan dengan pria yang menghamilinya (S/calon suami). \\
\hline
\end{tabular}

Sumber: Diadaptasi dari Putro (2011).

Dalam Pasal 53 ayat (1) disebutkan bahwa wanita hamil di luar nikah, dapat dikawinkan dengan pria yang menghamilinya. Dari hasil silogisme tersebut (Tabel 1) dapat diketahui bahwa kehamilan $\mathrm{W}$ (pemohon) merupakan akibat hubungan badan di luar nikah yang dilakukannya dengan $\mathrm{S}$ (calon suami), atau dengan kata lain $\mathrm{S}$ (calon suami) adalah pria yang telah menghamili W (pemohon), sehingga antara keduanya tidak ada halangan untuk melangsungkan perkawinan dan dapat melangsungkan perkawinan tanpa menunggu $\mathrm{W}$ (pemohon) melahirkan. Kemudian dalam Pasal 53 ayat (2), dapat diperoleh penjelasan secara implisit bahwa jika wanita hamil karena zina menikah dengan pria yang menghamilinya, tidak ada kewajiban untuk menjalankan iddah. Seperti dijelaskan dalam ayat (2) bahwa wanita tersebut dapat langsung dikawinkan dengan pria yang menghamilinya tanpa harus menunggu kelahiran anaknya (Ghazaly, 2008:124). Sebagaimana dalam putusannya berbunyi sebagai berikut:

"Menimbang, bahwa selanjutnya tentang rencana pernikahan pemohon yang sedang hamil di luar nikah dengan laki-laki yang menghamili yang dijadikan calon suami (S), berdasarkan ketentuan Pasal 53 Kompilasi Hukum Islam, pernikahan tersebut dapat dibenarkan tanpa harus menunggu kelahiran anaknya."

Dworkin mengingatkan bahwa seorang hakim ketika dihadapkan pada kasus konkret tidak saja berurusan dengan masalah teknis (prosedural) semata, tetapi juga berhadapan dengan substansi hukum. Ketika seorang hakim mempersoalkan masalah etika, bukan lagi bertanya tentang prosedur teknis penyelesaian hukum, tetapi juga mempersoalkan substansi hukum apakah adil atau tidak. Upaya hakim berusaha keras mencarikan hukumnya dari berbagai sumber hukum, tidak hanya membaca teks hukum formal melainkan juga sumber non-hukum patut dihargai. Hal ini dilakukan karena setiap kasus (baik "hard cases" maupun "clear cases") pada hakikatnya unik sehingga memerlukan interpretasi hukum yang baru. Karena itu, hakim harus melakukan "fresh judgement" untuk menemukan hukum yang tepat (Putro, 2011:206-208).

Majelis hakim melakukan penemuan hukum terhadap perkara tersebut yang termuat dalam pertimbangan hukum, yang kemudian dirumuskan menjadi amar putusan. Kemudian peneliti mengambil dua poin penetapan yang perupakan poin inti dalam amar putusan tersebut, di antaranya:

Pertama, mengenai pencabutan surat penolakan perkawinan yang dikeluarkan oleh KUA Kedungwaru Kabupaten Tulungagung, yang berbunyi:

"Menyatakan, Surat Penolakan Pernikahan dari Kantor Urusan Agama Kecamatan Kedungwaru, Kabupaten Tulungagung, Nomor B-252/Kua.15.04.15/ PW.01/09/2017, tanggal 12 September 2017, tidak mempunyai kekuatan berlaku." 
Poin ini menyatakan bahwa penetapan tersebut telah sesuai dengan aturan hukum mengenai iddah hamil, yaitu: ketetapan iddah hamil sebagaimana yang dinyatakan dalam surat penolakan perkawinan yang dikeluarkan oleh KUA Kedungwaru Kabupaten Tulungagung, tidak dapat diberlakukan terhadap W (pemohon) karena kehamilannya tersebut bukan dengan suaminya, akan tetapi dengan S (calon suami), meskipun kehamilan $\mathrm{W}$ (pemohon) tersebut terjadi dalam masa iddah. Sehingga surat penolakan perkawinan dalam masa iddah yang dikeluarkan oleh pihak KUA tidak terbukti dan dinyatakan tidak mempunyai kekuatan hukum.

Hal ini juga sesuai dengan ketentuan maslahah-mursalah, bahwa mashlahah sendiri merupakan tindakan yang diambil untuk menciptakan suatu kebaikan dan menghilangkan kesusahan bagi manusia (Al-Fitri, 2007:19). Di mana dengan dicabutnya surat penolakan perkawinan tersebut, maka perkawinan antara $\mathrm{W}$ (pemohon) dengan S (calon suami) sudah tidak ada halangan untuk dilaksanakan karena memang syarat-syaratnya sudah terpenuhi. Pada putusan ini, secara eksplisit dapat menghilangkan kesusahan bagi W (pemohon) yang mengajukan permohonan tersebut, agar tidak kesusahan dalam menanggung janin yang dikandungnya karena dapat dilangsungkannya pernikahan dengan $\mathrm{S}$ (calon suami) dan dapat menjadikan janin tersebut lahir dalam status perkawinan yang sah, baik secara agama maupun negara. Kemudian nantinya setelah adanya ikatan perkawinan dapat menghadirkan suatu ketenangan dan ketentraman karena W (pemohon) mendapat perlindungan, pemeliharaan, dan penjagaan dari suaminya. Ini merupakan suatu proses untuk menghilangkan kesusahan bagi W (pemohon), yang sebelumnya harus menanggung, melindungi, dan menjaga janin di dalam kandungannya dengan sendirian.

Kedua, mengenai pelaksanaan perkawinan antara W (pemohon) dengan S (calon suami), sebagaimana dalam amar putusannya berbunyi: "Memerintahkan kepada Pejabat Pencatat Nikah Kantor Urusan Agama Kecamatan Kedungwaru, Kabupaten Tulungagung, untuk melangsungkan serta mencatat pernikahan $\mathrm{W}$ (pemohon) dengan S (calon suami)" (Al-Fitri, 2007:19).

Poin ini menyatakan sebagaimana disebutkan dalam Pasal 53 ayat (1) bahwa wanita hamil di luar nikah, dapat dikawinkan dengan pria yang menghamilinya. Dari ketentuan tersebut dapat diketahui kehamilan W (pemohon) merupakan akibat hubungan badan di luar nikah yang dilakukannya dengan S (calon suami), sehingga antara keduanya tidak ada halangan untuk melangsungkan perkawinan dan dapat langsung dikawinkan tanpa harus menunggu lebih dahulu kelahiran anaknya (Ghazaly, 2008:124). Sehingga pernikahan antara keduanya tidak terdapat unsur yang menghalangi, karena dalam hukum positif maupun hukum Islam menikahkan antara seorang wanita hamil dengan pria yang menghamilinya merupakan suatu kebenaran, dan menyatakan bahwa hamilnya $\mathrm{W}$ (pemohon) tersebut bukan termasuk iddah hamil, karena iddah hamil terjadi jika kehamilannya tersebut dilakukan dengan suaminya (Hasunah \& Susanto, 2016:109).

Dalam hal ini menurut peneliti, sebagaimana amanat Pasal 5 ayat (1) UU Nomor 48 Tahun 2009 tentang Kekuasaan Kehakiman, yang menyebutkan bahwa: "Hakim dan hakim konstitusi wajib menggali, mengikuti, dan memahami nilai-nilai hukum dan rasa keadilan yang hidup dalam masyarakat." Pertimbangan hukum oleh majelis hakim dapat dikatakan tepat 
dalam menggunakan akal dan intelektualitasnya untuk melakukan penemuan hukum, sebagai upaya untuk memberikan penetapan secara adil yang dapat menciptakan kemaslahatan.

Secara eksplisit di luar pertimbangan hukum pada perkara ini, berdasarkan metode istishlah terkandung kemaslahatan di dalam penetapan tersebut, yaitu untuk menyelamatkan keturunan janin yang dikandung $\mathrm{W}$ (pemohon) tersebut tidak lain adalah dengan menikahkannya dengan pria yang menghamilinya yaitu $\mathrm{S}$ (calon suami) (Wahyudi, 2016:25-27), karena memang sesuai dengan peraturan perundang-undangan yang berlaku di Indonesia, bahwa anak yang sah adalah anak yang lahir di dalam perkawinan. Maka dari itu dengan adanya penetapan ini, kemaslahatan yang ditimbulkan ialah dianggap sahnya anak oleh hukum di Indonesia dan terjamin hak-hak keperdataan anak tersebut nantinya, seperti halnya mendapatkan akta kelahiran, kartu keluarga, dan kartu tanda penduduk untuk dilindungi hak-haknya tersebut oleh Pemerintah Republik Indonesia.

\section{KESIMPULAN}

Putusan Nomor 287/Pdt.P/2017/PA.TA yang mencabut surat penolakan perkawinan dalam masa iddah yang dikeluarkan KUA Kecamatan Kedungwaru Kabupaten Tulungagung memang sudah sesuai dengan landasan-landasan hukum yang ada, baik berupa hukum positif maupun hukum Islam. Hal ini dapat diketahui berdasarkan analisis yuridis terhadap Putusan Nomor 287/ Pdt.P/2017/PA.TA, di mana penemuan hukum (rechtvinding) yang digunakan oleh majelis hakim untuk mencari, menggali, dan menemukan hukumnya yakni menggunakan beberapa metode penemuan hukum (rechtvinding), di antaranya: Pertama, Metode Interpretasi Sistematis dan
Metode Istimbath yang digunakan untuk mengetahui bahwa masa iddah yang harus dijalani oleh W (pemohon) bukan iddah hamil akan tetapi iddah qurû'; Kedua, Metode $A$ Contrario (Argumen a Contrario) terhadap Pasal 153 ayat (2) huruf c KHI, yang digunakan untuk mengetahui siapa laki-laki yang telah menghamili W (pemohon), serta kejelasan mengenai status kehamilan W (pemohon) yang kemudian digunakan sebagai dasar untuk membatalkan surat penolakan perkawinan yang dikeluarkan oleh KUA; dan Ketiga, Silogisme yang digunakan untuk mengetahui bahwa di antara W (pemohon) dan S (calon suami) tidak ada halangan untuk melangsungkan perkawinan serta dapat melangsungkan perkawinan tanpa harus menunggu lebih dahulu kelahiran anaknya. Di dalamnya juga terdapat suatu kemaslahatan yaitu untuk menyelamatkan hak-hak keperdataan janin yang dikandung supaya nanti memperoleh akta kelahiran, akta keluarga, dan kartu tanda penduduk, karena dengan demikian akan mendapat perlindungan hukum dari Pemerintah Republik Indonesia.

\section{SARAN}

Berdasarkan pembahasan mengenai Putusan Nomor 287/Pdt.P/2017/PA.TA tentang pencabutan atas surat penolakan perkawinan dalam masa $i d d a h$ yang sudah diuraikan di atas, maka saran yang dapat penulis sampaikan bahwa, mengenai kewenangan hakim dalam memberikan putusan atau pun penetapan, di mana dalam hal ini terkait dengan upaya hakim dalam melakukan aktivitas penemuan hukum ketika dihadapkan pada peristiwa hukum konkret. Dalam persidangan majelis hakim tidak cukup menyalin pasal dalam peraturan perundang-undangan atau dengan kata lain bahwa hakim tidak hanya sebagai 
corong dari undang-undang, akan tetapi majelis hakim harus mencari, menggali, dan menemukan hukumnya dengan menggunakan metode penemuan hukum (rechtvinding), dengan harapan majelis hakim dapat mengisi kekosongan hukum atau menafsirkan suatu ketentuan hukum yang belum jelas ketentuannya. Karena pada dasarnya tidak ada peraturan perundang-undangan yang lengkap selengkap-lengkapnya dan jelas sejelasjelasnya dalam mencakup keseluruhan kehidupan manusia.

\section{DAFTAR ACUAN}

\section{Buku}

Al Hamdani, H.S.A. (2002). Risalah nikah; Hukum perkawinan Islam. Jakarta: Pustaka Amani.

Al-Fitri. (2007). Metode penemuan hukum (Bayani, Ta'lili \& Istislahi). Bandar Lampung: IAIN Raden Intan.

Ali, A. (2011). Menguak tabir hukum. Bogor: Ghalia Indonesia.

Ali, Z. (2011). Metode penelitian hukum. Jakarta: Sinar Grafindo.

. (2012). Hukum perdata Islam di Indonesia. Jakarta: Sinar Grafika.

Daradjat, Z. (2013). Ilmu fiqh. Jilid II. Cet. ke-2. Jakarta: t.p.

Ghazaly, A.R. (2008). Fiqh munakahat. Jakarta: Kencana.

Hamid, Z. (2000). Pokok-pokok hukum perkawinan Islam \& Undang-Undang Perkawinan di Indonesia. Yogyakarta: Bina Cipta.

HS, S. (2008). Pengantar hukum perdata tertulis
$(B W)$. Jakarta: Sinar Grafika.

Koentjaraningrat. (2008). Metode penelitian masyarakat. Jakarta: Gramedia.

Mahfiana, L. (2005). Ilmu hukum. Ponorogo: STAIN Ponorogo Press.

Mardani. (2011). Hukum perkawinan Islam di dunia Islam modern. Yogyakarta: Graha Ilmu.

Mertokusumo, S. (2010). Penemuan hukum. Yogyakarta: Universitas Atma Jaya.

Munawwir, A.W. (2002). Al Munawwir Kamus ArabIndonesia. Surabaya: Pustaka Progresif.

Musahadi. (2009). (Continuity \& change) reformasi hukum Islam: Belajar pada pemikiran Muhammad Iqbal \& Fazhar Rahman. Semarang: Walisongo Press.

Ramulyo, M.I. (2004). Hukum perkawinan Islam suatu analisis dari Undang-Undang No. 1 Tahun 1974 \& Kompilasi Hukum Islam. Jakarta: PT Bumi Aksara.

Rofiq, A. (2003). Hukum Islam di Indonesia. Jakarta: Raja Grafindo Persada.

Soekanto, S. \& Mamudji, S. (2010). Penelitian hukum normatif (Suatu tinjauan singkat). Jakarta: Raja Grafindo Persada.

Soekanto, S. (2006). Pengantar Penelitian Hukum. Jakarta: UI Press.

Sudarsono. (2001). Pokok-pokok hukum Islam. Jakarta: Asdi Mahasatya.

Sutiyoso, B. (2012). Metode penemuan hukum. Yogyakarta: UII Press.

Syarifuddin, A. (2006). Hukum perkawinan Islam di Indonesia antara fiqh munakahat \& UndangUndang Perkawinan. Jakarta: Prenada Media 


\section{Jurnal}

Elias, R.F. (2014). Penemuan hukum dalam proses peradilan pidana di Indonesia. Jurnal LPPM Bidang EkoSosBudKum, 1(1), 2-7.

Hasunah, U. \& Susanto. (2016, April). Iddah perempuan hamil karena zina dalam Kompilasi Hukum Islam Pasal 53. Jurnal Hukum Keluarga Islam, 1(1), 101-109.

Jauharatun. (2016, Desember). Hukum pernikahan janda dalam masa iddah menurut pandangan ulama Palangka Raya. Jurnal Studi Agama dan Masyarakat, 12(2), 160-164.

Tobroni, F. (2016). Penafsiran hukum dekonstruksi untuk pelanggaran poligami. Jurnal Yudisial, 5(3), 281-301.

Wahyudi, M.I. (2016, Maret). Kajian kritis ketentuan waktu tunggu (Iddah) dalam RUU HMPA bidang perkawinan. Jurnal Hukum dan Peradilan, 5(1), 25-27.

\section{$\underline{\text { Sumber lainnya }}$}

Putro, W.D. (2011). “Tinjauan kritis-filosofis terhadap paradigma positivisme hukum." Disertasi. Jakarta: Universitas Indonesia. 